\title{
Free Trade Agreements, Institutions and the Exports of Eastern Partnership Countries*
}

\author{
THORVALDUR GYLFASON, ${ }^{1}$ INMACULADA MARTÍNEZ-ZARZOSO ${ }^{2}$ and PER MAGNUS WIJKMAN ${ }^{3}$ \\ ${ }^{1}$ University of Iceland and CESifo. ${ }^{2}$ Georg-August University Göttingen and University Jaume I, Castellón. ${ }^{3}$ University of Göteborg, \\ Gothenburg
}

\begin{abstract}
Following popular protests at home and the fall of the government, Ukraine reversed course and joined Georgia and Moldova in signing Association Agreements in June 2014. This article has two main aims. First, using a gravity model of trade, it estimates the effects of deep and shallow free trade agreements for the EaP (Eastern Partnership) states with Russia and the EU respectively. Second, by relating the outcomes of the first estimation to the quality of institutions, proxied with the level of democracy and the level of corruption in the selected countries, the paper estimates the effect on exports of changes in the quality of institutions. The main results show that the EaP countries gain significantly from free trade agreements with the EU but little if anything from free trade agreements with Russia, and that improvements in the quality of institutions in EaP countries have played an important role in fostering exports.
\end{abstract}

Keywords: Free trade agreements; Eastern Partnership; European Union; gravity model; panel data; institutions.

\section{Introduction}

In July 2013 the European Union (EU) announced that it had completed negotiations, started early in 2012, on Association Agreements, including deep and comprehensive free trade agreements (DCFTA), with Armenia, Georgia and Moldova. These agreements were to be initialled at the EaP (Eastern Partnership) Summit in Vilnius on 28-29 November 2013. The successful negotiation of DCFTAs with these three States in the short period of 18 months surprised many observers. ${ }^{1}$ The DCFTA agreement with Ukraine, already initialled, was to be signed at the same time, subject to prior fulfillment by Ukraine of certain conditions concerning, inter alia, its application of 'selective justice'.2

\footnotetext{
* This paper was presented at the 16th Annual Swedish Network for European Studies in Economics and Business (SNEE) European Integration Conference in Mölle, Sweden, 20-23 May 2014. The authors thank their discussant, Hubert Fromlet, and also Michael Emerson, Helga Kristjánsdóttir, Alexander Libman and three referees for reactions to earlier versions of the paper. The authors acknowledge the support and collaboration of Project ECO2014-58991-C3-2-R funded by the Spanish Ministry of Economy and Competitiveness and of Project 'Production Networks and Economic Integration' funded by Fundación Caja Castellón-Bancaja.

${ }^{1}$ Negotiating the DCFTA had taken Ukraine five years and starting negotiations had taken Georgia almost four years. Armenia was a latecomer and had worse initial conditions than Georgia. The decision to start negotiations in 2012 and their rapid conclusion were surprising. Compared with these countries, Moldova had a head-start through its negotiation of a regional free trade agreement with the Western Balkans (CEFTA 2006) in close co-operation with the EU.

${ }^{2}$ This refers most notably to the trial and imprisonment of former prime minister Yulia Timoshenko after Viktor Yanukovich assumed the presidency in January 2010.
} 
What was to follow was even more surprising. In September 2013, Armenia announced that it would not initial its Association Agreement in Vilnius but would instead join the ECU (Eurasian Customs Union) proposed by Russia. Armenia's decision could have been influenced by Russia's threat otherwise to withdraw its troops from Azerbaijan, which protected the region of Nagorno Karabahk, largely populated by Armenians. A few days before the summit, President Yanukovich of Ukraine announced that he would postpone signing the Association Agreement with the EU after Russia had offered significant loans.

President Yanukovich's decision had fateful consequences. Prolonged demonstrations in Maidan Square in Kiev ended in violence and President Yanukovich fled the country on 21 February 2014. The next day Parliament elected a provisional president and installed a new government. Within a week, armed 'self-defence groups' appeared in Crimea and on 21 March, President Putin signed documents admitting Crimea and Sevastopol into the Russian Federation. Since then, war has raged in the Donetsk and Luhansk region.

Georgia, Moldova and Ukraine signed the Association Agreements and DCFTAs with the EU on 27 June 2014. The agreements require ratification by each EU Member State and the European Parliament.

This article assesses the benefits of various integration regimes on exports. More specifically, it evaluates and compares the effects of FTAs (free trade agreements) signed by EaP countries with the EU and with Russia, and the role played by the quality of institutions (democracy and corruption) in fostering trade. We focus on the effects of both deep and shallow FTAs on exports. While recognizing that FTAs may lead not only to trade creation but also to trade diversion, we assume that the most likely result is an improvement in welfare.

The estimation strategy employed follows the most recent literature (Baier and Bergstrand, 2007; Eicher et al., 2012; Head and Mayer, 2015) suggesting the use of country-pair fixed effects to control for the endogeneity of the FTA effects and the use of exporter-and-time and importer-and-time dummy variables to control for the so-called multilateral resistance factors.

The results suggest that the EaP countries, with Ukraine by far the largest in the group, gain significantly from FTAs with the EU, but gain little if anything from FTAs with Russia. The quality of institutions in EaP countries plays an important role in fostering trade.

The article is organized as follows. Section I presents the main theoretical framework, describes the data and variables and specifies the econometric models. Section II presents the main results in terms of trade gains from recently signed DCFTAs and Section III relates trade flows with improvements in institutional quality. Section IV discusses the main trade policy alternatives for EaP countries and proposes strengthening the EaP framework and involving Russia. After this we conclude.

\section{The Scope of Potential Trade}

To quantify the trade effects of the different FTAs on bilateral exports we use the gravity model of trade, a theoretical apparatus often used to estimate the effects of trade agreements. Specifically, we assess how the trade flows of the EaP States will be affected by:

- Entering into the EU, full membership (EU)

- A DCFTA with:

- EU (EUdeep) 
- Russia (RUSdeep)

- A shallow FTA with:

- EU (EUshallow)

- Russia ${ }^{3}$ (RUSshallow)

- Each of the EaP states (FTA-East)

We also say something about the intermediate case, which is likely to be the outcome for the next few years if Georgia, Moldova and perhaps Ukraine as well turn west while Azerbaijan, Armenia and Belarus turn east.

We first present the data we use, the empirical models and methods, the results of alternative regional integration scenarios and further results relating trade to the quality of institutions.

\section{Data and Variables}

We obtain bilateral exports for 60 exporters and 150 importers ${ }^{4}$ from the UNCOMTRADE database for the period 1995 to 2012 and data on income variables from the World Bank (World Development Indicators, 2014). We computed distances between capitals and other gravity dummies (common border, common language, colonial relationship and having been part of the same country) using data from the Centre d'Etudes Prospectives et d'Informations Internationales (CEPII). The FTA variable was constructed based on data from the World Trade Organization and from De Sousa (2012), as well from the European Commission (see Table A.1). Table 1 presents the summary statistics of the above variables. The FTA variables considered are listed in the lower part of Table 1. In Section III we add democracy (i.e., the Polity2 variable from the Polity IV project) as well as corruption data from the International Country Risk Guide (ICRG). ${ }^{5}$

\section{Method of Estimation}

In the past two decades the main ex-post method used to estimate the effects on trade of FTAs has been based on the gravity model of trade, a 'workhorse' model of bilateral trade (Feenstra, 2004). This model has evolved into a sophisticated tool to analyse the broad determinants of bilateral trade flows, among them a number of policy factors such as FTAs, trade facilitation factors, tariffs, regulations, etc.

As regards the techniques used to estimate the model, the main novelties are reviewed by Head and Mayer (2015) and Baltagi et al. (2014). Head and Mayer (2015) review the main trade theories supporting the model and the estimation challenges involved to be able to identify accurately the effects on trade of specific economic and political factors.

\footnotetext{
${ }^{3}$ We assume that the announcement of the formation of the Common Economic Space by Russia could be close to a shallow FTA, so that the RUSshallow dummy variable used in the empirical analysis takes the value of one for trade between Russia, Belarus, Kazakhstan and Ukraine starting in 2004. An alternative definition of RUSshallow was used (Eurasian Economic Community) and the results remain the same. See online Appendix for a discussion of the whole set of PostSoviet integration agreements.

${ }^{4}$ The countries included in the sample are listed in Appendix Table A.2 Supporting Information. The exporters considered are EU countries plus all European, North African and Middle East countries that are EU neighbours.

${ }^{5}$ ICRG offers an index of corruption, coding corruption in different countries on a scale from zero to six, with high scores indicating low levels of corruption. The ICRG measure has extensive coverage and uses a single survey methodology for all countries, which permits comparisons across countries and over time. This index is highly correlated with alternative corruption measures, including corruption perceptions scores compiled by Transparency International.
} 
Table 1: Summary statistics

\begin{tabular}{lcclcc}
\hline Variable & Obs & Mean & Std. Dev. & Min & Max \\
\hline Exports & 164700 & $4.79 \mathrm{e}+08$ & $3.42 \mathrm{e}+09$ & 0 & $1.43 \mathrm{e}+11$ \\
Lnexports & 121249 & 15.93 & 3.590 & 0 & 25.68 \\
Lngdpi & 163350 & 24.82 & 1.884 & 20.57 & 28.92 \\
Lngdpj & 161650 & 24.07 & 2.190 & 18.72 & 30.42 \\
Lndist & 164700 & 8.36 & .864 & 1.90 & 9.88 \\
Contig & 164700 & .024 & .152 & 0 & 1 \\
Comcol & 164700 & .058 & .233 & 0 & 1 \\
Smctry & 164700 & .007 & .083 & 0 & 1 \\
Comlang & 164700 & .086 & .281 & 0 & 1 \\
EU & 164700 & .066 & .248 & 0 & 1 \\
Eushallow & 164700 & .056 & .230 & 0 & 1 \\
Etdeep & 164700 & .005 & .071 & 0 & 1 \\
RUSdeep & 164700 & .058 & .234 & 0 & 1 \\
RUSshallow & 164700 & .045 & .208 & 0 & 1 \\
Turkey & 164700 & .0002 & .016 & 0 & 1 \\
FTA-East & 164700 & .003 & .056 & 0 & 1 \\
\hline
\end{tabular}

Note: In denotes natural logarithms, exports are in thousands of US\$. gdpi and gdpj denote gross domestic product of exporter and importer country, respectively. Dist is distance between capital cities of origin and destination countries. Contig, comcol, smctry and comlang are dummy variables that take the value of 1 when the trading countries share a border, have ever had a colonial relationship, were part of the same country in the past, or have a common language, respectively.

Baltagi et al. (2014) focus instead on presenting the econometric techniques proposed most recently to estimate these effects consistently and efficiently. We follow these papers in our choice of model specifications and estimation techniques.

According to the underlying theory that has been reformulated and extended by Anderson and van Wincoop (2003), our model assumes a constant elasticity of substitution and product differentiation by place of origin. In addition, prices differ among locations due to symmetric bilateral trade costs. The reduced form of the model is specified as

$$
\mathrm{X}_{i j t}=\frac{\mathrm{Y}_{i t} \mathrm{Y}_{j t}}{\mathrm{Y}_{t}^{W}}\left(\frac{\mathrm{t}_{i j t}}{P_{i t} P_{j t}}\right)^{1-\sigma}
$$

The empirical specification in log-linear form is given by

$$
\text { 圤 } X_{i j t}=\ln Y_{i t}+\ln Y_{j t}-\ln Y_{t}^{W}+(1-\sigma) \ln t_{i j t}-(1-\sigma) \ln P_{i t}-(1-\sigma) \ln P_{j t}
$$

where $X_{i j t}$ is bilateral exports from country $i$ to country $j$ in year $t$, and $Y_{i t}, Y_{j t}$ and $Y_{t}^{W}$ are the gross domestic products in the exporting country, the importing country and the world in year t. $t_{i j t}$ denotes trade costs between the exporter and the importer in year $t$ and $P_{i t}$ and $P_{j t}$ are the so-called multilateral resistance terms. ${ }^{6} \sigma$ is the elasticity of substitution between all goods.

\footnotetext{
${ }^{6}$ Multilateral resistance terms reflect relative trade costs with respect to the rest of the world. This concept was introduced by Anderson and van Wincoop (2003) into the gravity model. Bilateral trade is not only affected by bilateral interactions, but also by interactions with the rest of the world.
} 
The estimation of equation (2) is not straightforward due to the presence of trade costs and multilateral resistance terms. The trade cost function is assumed to be a linear function of a number of trade barriers, namely the time-invariant determinants of trade flows, including distance, common border, common colonial past and common language dummies and the time-varying FTA variable. In line with the recent gravity literature the multilateral resistance terms are modelled as time-varying or time-invariant countryspecific dummies, depending on the estimation procedure. Substitution of the trade cost function into equation (2) with an idiosyncratic error term suggests estimating

$$
\begin{aligned}
\ln \left(X_{i j t}\right)= & a_{0}+a_{1} \ln Y_{i t}+a_{2} \ln Y_{j t}+a_{3} \ln D_{i j}+a_{4} \text { Lang }_{i j}+a_{5} \text { Colony }_{i j}+ \\
& a_{6} \text { Border }_{i j}+a_{7} \text { Smctry }_{i j}+a_{8} F T A_{i j t}+\gamma_{t}+u_{i j t}
\end{aligned}
$$

where $D_{i j}$ denotes geographical distance from country $i$ to country $j$, Lang $_{\mathrm{ij}}$ and Colony $y_{i j}$ take the value of one when countries $i$ and $j$ share official language or have ever had a colonial relationship and zero otherwise, Border $_{i j}$ takes the value of one when the trading countries share a border and zero otherwise, Smctry ${ }_{i j}$ takes the value of one when countries $i$ and $j$ were part of the same country in the past and $F T A_{i j t}$ takes the value of one when the trading countries are members of an FTA and zero otherwise. $\gamma_{t}$ denotes a set of year dummies that proxy for business cycle and other time-variant common factors (globalization) that affect all trade flows in the same manner.

In equation (4) we introduce a set of dummies, $d_{i t}$ and $d_{j t}$, to control for the multilateral resistance terms. We are still able to estimate the coefficients of the income variables because we construct country-and-time dummies that vary every five years (y) instead of yearly (t). In addition, rather than adding the usual time-invariant gravity variables to control for differences in trade costs (distance, etc.), we use country-pair fixed effects $\left(\gamma_{i j}\right)$ to control for bilateral unobserved characteristics. The equation is given by

$$
\ln \left(X_{i j t}\right)=\gamma_{i j}+\beta_{1} \ln Y_{i t}+\beta_{2} \ln Y_{j t}+\beta_{3} R T A_{i j t}+\sum d_{i y} I_{i y}+\sum d_{j y} I_{j y}+u_{i j t} .
$$

Our initial estimation strategy follows Baier and Bergstrand (2007), Eicher et al. (2012) and Head and Mayer (2015), suggesting the use of country-pair fixed effects to control for endogeneity of the FTA effects and the use of exporter-and-time and importer-and-time dummy variables to control for so-called multilateral resistance factors (for comparison, we present the usual fixed effects estimation with only bilateral fixed effects and time fixed effects). Additional problems that arise in the estimation are caused by the presence of zero trade flows and heteroscedasticity in the error term (non-constant variance in the unexplained part of the model). To tackle these two issues we estimate the model as suggested in Head and Mayer (2015), using a multinomial Pseudo Maximum Likelihood (MPML) estimation following Eaton et al. (2012) and an EK-Tobit as in Eaton and Kortum (2001). The MPML consists of estimating a Poisson model using the market share $\left(X_{i j} / X_{j}\right)$ as the dependent variable and adding country-specific fixed effects as regressors. The model specification is given by

$$
\begin{aligned}
\frac{X_{i j t}}{X_{j t}}= & \gamma_{t}+\beta_{1} \ln Y_{i t}+\beta_{2} \ln Y_{j t}+\beta_{3} \ln D_{i j}+\beta_{4} \text { Lang }_{i j}+\beta_{5} \text { Colony }_{i j}+ \\
& \beta_{6} \text { Border }_{i j}+a_{7} \text { Smctry }_{i j}+\beta_{8} F T A_{i j t}+\sum d_{i} I_{i}+\sum d_{j} I_{j}+\varepsilon_{i j t} .
\end{aligned}
$$


The EK-Tobit consists of replacing the zero trade flows $\left(X_{i j}\right)$ with the minimum value of the dependent variable for a given origin $\left(X_{i j}\right.$, min for all $\left.j\right)$ and the natural $\log$ of the new variable is used as the dependent variable in a Tobit-type regression (intreg in Stata).

The selection of the appropriate estimator depends on the process generating the error term. Under the assumption of a Poisson-type error term it would be better to use MPML or the Poisson Pseudo Maximum Likelihood (PPML) but, under log-normality, EK-Tobit is preferred. The solution proposed here is to assume that all missing values are zeros and then use a MaMu (Manning and Mullahy, 2001) test to check for the process generating the error term. ${ }^{7}$ Since we could not reject the assumption of a Poisson-type error term in our data, we estimated the gravity model using the MPML as suggested by Head and Mayer (2015).

Alternative approaches to estimating the gravity model of trade, including zero trade flows, have been proposed. Helpman et al. (2008) suggest a two-step approach in which first, the probability to export to a given destination is estimated, and in the second step some elements of the first step are incorporated in the estimation of the positive trade values - namely, a control for sample selection and a control for firm heterogeneity. Davies and Kristjánsdóttir (2010) use a Heckman two-step approach (Heckman, 1979), controlling for selection bias in the second step where the dependent variable is the magnitude of exports given that exports are positive. We also use these procedures as a robustness check on our results.

\section{Main Results of Various Regional Integration Agreements}

The DCFTAs recently signed by the EU include not only trade issues, but also an increasing number of provisions concerning foreign investment, competition policy, sanitary and phytosanitary standards, technical regulations, intellectual property rights, rules of origin, etc. The EU's DCFTAs are significantly more extensive than those previously applied or currently proposed by Russia. We try to identify the trade effect of specific agreements by focusing specifically on their scope. For instance, the EU has signed DCFTAs with several countries since 2000, the effects of which can already be identified and could be comparable in scope to the DCFTAs negotiated with Armenia, Georgia, Moldova and also Ukraine. $^{8}$ But these countries could instead decide to reverse course, as Armenia did already, and join the ECU, thus remaining under Russia's influence. The main aim of this section is to evaluate the trade effects of agreements with Russia compared with trade agreements with the EU and thereby to add some economic reasoning to the political debate. To this end, we will distinguish between FTAs proposed by Russia, including the Common Economic Space ${ }^{9}$ (RUSshallow) and ECU (RUSdeep), ${ }^{10}$ and FTAs or DCFTAs proposed by the EU and estimate their trade effects. Appendix Table A.1 lists the agreements we considered that were in place during the period under study. ${ }^{11}$

\footnotetext{
${ }^{7}$ See Martínez-Zarzoso (2013, p. 321, eq. 13). The results from the test are available upon request. In some cases, the test results were inconclusive. Hence, we also present the results obtained from the EK-Tobit model.

${ }^{8}$ The DCFTAs considered are with Albania (2006), Croatia (2002) and Macedonia (2001).

${ }^{9}$ The Common Economic Space was announced in 2003 and involved Belarus, Kazakhstan, the Kyrgyz Republic, Russia and Ukraine. The RUSshallow dummy variable will take the value of 1 after 2004 for these countries.

${ }^{10}$ We assume that the ECU became operational in 2010, as suggested by a reviewer.

${ }^{11}$ We consider FTAs as shallow agreements and FTA\&EIA or CU\&EIA as DCFTAs (Table A.1).
} 
Table 2: Gravity model: Baseline results

(1)

Fixed effects

Dependent variable:

\begin{tabular}{lc}
\hline Lngdpi & $0.704^{* * *}$ \\
Lngdpj & {$[0.0408]$} \\
& $0.648^{* * *}$ \\
EU (full membership) & {$[0.0265]$} \\
& $0.215^{* * *}$ \\
EUshallow & {$[0.0359]$} \\
& $0.101^{* * *}$ \\
EUdeep & {$[0.0301]$} \\
& $0.285^{* * *}$ \\
RUSdeep & {$[0.0835]$} \\
& $-0.161^{* * *}$ \\
RUSshallow & {$[0.0571]$} \\
& -0.0783 \\
Turkey & {$[0.0485]$} \\
& 0.150 \\
FTA-East & {$[0.164]$} \\
& -0.267 \\
Constant & {$[0.233]$} \\
& $-17.73 * * *$ \\
Time Fixed Effects & {$[1.200]$} \\
Observations & Yes \\
R-squared (within) & 116,293 \\
Number of bilateral pairs & 0.246 \\
\end{tabular}

(2)

Fixed effects with MRT1 Ln exports

$0.480^{* * *}$

[0.0342]

$0.699 * * *$

[0.0293]

$0.152 * * *$

[0.0466]

$-0.0376$

[0.0325]

$0.356 * * *$

[0.0931]

$0.301 *$

[0.157]

$-0.00533$

[0.0549]

$-0.317$

[0.256]

$-0.126$

[0.214]

$-13.05^{* * * *}$

[0.648]

Country-specific

116,293

0.291

8,268
(3)

MPML with MRT2

Export share

Note: Robust standard errors within brackets. ***p $<0.01, * * \mathrm{p}<0.05, * \mathrm{p}<0.1$

FE denotes bilateral fixed effects and MRT1 denotes multilateral resistance terms (exporter-and-time and importer-and-time dummy variables). MTR2 denotes exporter and importer dummy variables. Coefficients for bilateral variables are omitted in column (3). MPML denotes Multinomial Pseudo Maximum Likelihood. The variables are defined in the note below Table 1. ${ }^{\mathrm{a}}$ Pseudo $\mathrm{R}^{2}$.

We estimate equations (4) and (5) for a panel of 60 exporters and 150 importers in the period 1995 to 2012 (see Appendix Table A.2 for a list of countries).

The baseline results are presented in Table 2. The first column presents the result of estimating a variation of equation (3) with bilateral fixed effects $\left(\gamma_{i t}\right)$ and time fixed effects $^{12}\left(\gamma_{i t}\right)$ and the second column presents the result of estimating equation (4) with the multilateral resistance proxies (exporter-and-time and importer-and-time dummies) and with bilateral fixed effects. Column (3) shows the result of applying the MPML method with zero trade flows and with export shares as dependent variable (equation (5)).

Our results suggest that entering into trade agreements with the EU provides a greater stimulus to trade than joining the agreements promoted by Russia. Consider first column (3), where row 3 shows that full accession to the EU (2004 and 2007 enlargements)

\footnotetext{
12 The coefficients of the time-invariant bilateral variables (distance, common language, common colony and same country) cannot be directly estimated and are subsumed in the bilateral fixed effects.
} 
increased export shares by 311 percent $\left(\mathrm{e}^{1.413}-1=3.11\right)$; however, as stated above, this is not an explicit option for EaP countries.

Consider next the effect of trade agreements with the EU and with Russia. A DCFTA with the EU (EUdeep, row 5) will increase export shares less than full membership, or by 86 per cent $\left(\mathrm{e}^{0.578}-1=0.86\right)$, whereas a DCFTA with Russia (RUSdeep, row 6) will not result in any significant increase in export shares for the EaP countries considered. We surmise that this result reflects the fact that FTAs with Russia are less deep and less strictly implemented than comparable FTAs with the EU.

As regards the shallow FTAs, the results are less stable and vary widely across specifications, making them less robust. By including zero trade in column (3) the estimate for a shallow FTA with the EU is quite high - export shares will be nine times larger - and probably biased upwards, whereas according to column (2) there is no effect on trade. ${ }^{13}$ On the other hand, our results suggest that the announcement of forming a Common Economic Space with Russia (shallow FTA) has not had positive effects on trade; in fact, the results in column (3) suggest that trade will even be reduced (RUSshallow). Finally, a shallow FTA among EaP States will result in nearly a trebling of export shares $\left(\mathrm{e}^{1.287}-1=2.62\right)$ by column $(3)$. Again, the effects are probably exaggerated because we only have data since 1995/1996 for some countries among which trade has expanded rapidly in recent years, as well as due to possible measurement errors in the trade data in the early years of the sample. Even so, our results accord with those of Fidrmuc and Fidrmuc (2003), who report evidence of strong home bias in trade within east and central Europe (see also Djankov and Freund, 2002).

Many have observed that agreements with the EU are likely to eliminate a wider range of trade barriers on a wider range of commodities and services than agreements with Russia. In addition, they are implemented more effectively than those between Eurasian countries. Thus, we are not comparing like with like agreements, but a typical agreement with Russia with a typical similar agreement with the EU. Our results confirm econometrically the findings of previous case studies that agreements with Russia produce inferior results. ${ }^{14}$ The former Soviet Republics have had great difficulty in creating the institutions necessary to implement rules and procedures required by well-functioning market economies.

Table 3 presents the results from using alternative estimation techniques to tackle zero trade. Here we also present estimates for the other bilateral time-invariant variables, since the fixed effects included in Table 3 are exporter and importer fixed effects rather than bilateral (country-pair) fixed effects. The first column uses the same method as in column 3 of Table 2, but shows different effects for specific EaP countries, namely Armenia, Georgia and Ukraine. Columns 2 and 3 present estimates obtained by using alternative estimation techniques that also consider the existence of zero trade flows in the data, an EK-Tobit model in column 2 and a PPML model in column 3.

The results in Columns 2 and 3 accord with those reported in Column 1 concerning the sign and significance of the effects. FTAs with the EU, deep or shallow, ${ }^{15}$ boost trade,

\footnotetext{
${ }^{13}$ Missing and zero export flows are excluded from the estimation in column 2, but we are able to control for time-variant multilateral resistance factors (MRT1), whereas we are only able to control for time-invariant multilateral resistance factors (MRT2) in column 3, because the estimation of the model does not converge with MRT1.

${ }^{14}$ Kubicek, 2009; Libman, 2007; Olcott, Aslund and Garnett, 1999; Wirminghaus, 2012.

15 The results for EU shallow bilateral agreements shown in columns 2 and 3 of Table 3 suggest that trade increases by $6.2 \%$ and $25 \%$, respectively, in keeping with the view that more trade gains should be expected from signing deep agreements rather than shallow ones. This is not the case in the results obtained for the model estimated with export shares.
} 
Table 3: Gravity model: Sensitivity analysis

\begin{tabular}{|c|c|c|c|}
\hline Dependent variable: & $\begin{array}{c}(1) \\
\text { MPML with MRT2 } \\
\text { Export Share }\end{array}$ & $\begin{array}{c}(2) \\
\text { EK-Tobit with MRT2 } \\
\text { Ln Exports }\end{array}$ & $\begin{array}{c}(3) \\
\text { PPML with MRT2 } \\
\text { Exports }\end{array}$ \\
\hline \multirow[t]{2}{*}{ Lngdpi } & $0.533 * * *$ & $0.446^{* * *}$ & $0.678 * * *$ \\
\hline & {$[0.0788]$} & [0.0329] & {$[0.0535]$} \\
\hline \multirow[t]{2}{*}{ Lngdpj } & $0.716^{* * * *}$ & $0.558 * * *$ & $0.609 * * *$ \\
\hline & {$[0.0628]$} & {$[0.0230]$} & {$[0.0482]$} \\
\hline \multirow[t]{2}{*}{ Lndist } & $0.0578 * *$ & $-1.561 * * *$ & $-0.0621 * *$ \\
\hline & {$[0.0277]$} & {$[0.0151]$} & {$[0.0254]$} \\
\hline \multirow[t]{2}{*}{ Contig } & $1.030 * * *$ & $0.150 * * *$ & $0.989 * * *$ \\
\hline & {$[0.0423]$} & [0.0392] & [0.0397] \\
\hline \multirow[t]{2}{*}{ Comcol } & 0.167 & $1.317 * * *$ & $1.067 * * *$ \\
\hline & [0.117] & {$[0.0318]$} & [0.0908] \\
\hline \multirow[t]{2}{*}{ Smctry } & $0.727 * * *$ & $0.604 * * *$ & $0.505^{* * *}$ \\
\hline & {$[0.0634]$} & [0.0659] & {$[0.0460]$} \\
\hline \multirow[t]{2}{*}{ Comlang } & $0.142 * * *$ & $0.917 * * *$ & $0.369 * * *$ \\
\hline & {$[0.0522]$} & {$[0.0221]$} & [0.0296] \\
\hline \multirow[t]{2}{*}{ EU } & $1.414 * * *$ & $0.0881 * * *$ & $0.483 * * *$ \\
\hline & [0.0769] & {$[0.0222]$} & {$[0.0458]$} \\
\hline \multirow[t]{2}{*}{ EUshallow } & $2.302 * * *$ & $0.0670 * * *$ & $0.187 * * *$ \\
\hline & {$[0.0705]$} & {$[0.0195]$} & {$[0.0349]$} \\
\hline \multirow[t]{2}{*}{ EUdeep } & $0.578 * * *$ & $0.269 * * *$ & $0.330 * * *$ \\
\hline & {$[0.103]$} & [0.0599] & {$[0.0788]$} \\
\hline \multirow[t]{2}{*}{ RUSdeep } & 0.0562 & -0.107 & -0.0301 \\
\hline & {$[0.123]$} & [0.0683] & {$[0.0824]$} \\
\hline \multirow[t]{2}{*}{ RUSshallow } & $-0.160 * *$ & -0.0374 & $-0.125 * *$ \\
\hline & [0.0809] & [0.0419] & {$[0.0584]$} \\
\hline \multirow[t]{2}{*}{ Turkey } & $2.312 * * *$ & $0.615 * * *$ & $1.278 * * *$ \\
\hline & {$[0.634]$} & [0.0996] & {$[0.117]$} \\
\hline \multirow[t]{2}{*}{ Armenia } & $1.841 * * *$ & $0.839 * * *$ & $1.118 * *$ \\
\hline & {$[0.375]$} & {$[0.258]$} & {$[0.443]$} \\
\hline \multirow[t]{2}{*}{ Georgia } & $2.452 * * *$ & $3.166^{* * *}$ & $2.512 * * *$ \\
\hline & {$[0.122]$} & {$[0.112]$} & {$[0.131]$} \\
\hline \multirow[t]{2}{*}{ Ukraine } & $1.111 * * *$ & $1.159 * * *$ & $0.367 * * *$ \\
\hline & {$[0.152]$} & {$[0.0910]$} & {$[0.122]$} \\
\hline \multirow[t]{2}{*}{ FTA-East } & $1.287 * * *$ & $1.573 * * *$ & $0.555^{* * * *}$ \\
\hline & {$[0.145]$} & {$[0.0812]$} & [0.119] \\
\hline Country Fixed Effects & Yes & Yes & Yes \\
\hline Time Fixed Effects & Yes & Yes & Yes \\
\hline Observations & 157721 & 157721 & 157721 \\
\hline Pseudo $\mathrm{R}^{2}$ & 0.390 & -- & 0.906 \\
\hline Log pseudolikelihood & -160.248 & $-233398,610$ & $-2.204 e+13$ \\
\hline
\end{tabular}

Note: Robust standard errors within brackets. $* * * \mathrm{p}<0.01,{ }^{*} \mathrm{p}<0.05,{ }^{*} \mathrm{p}<0.1$. MRT2 denotes multilateral resistance terms (exporter and importer dummy variables). M(P)PML denotes Multinomial (Poisson) Pseudo Maximum Likelihood. The variables are defined in the note below Table 1. The effects shown in line FTA-East were calculated in a separate regression that excluded FTAs with Armenia, Georgia and Ukraine.

whereas FTAs with Russia do not (they may even reduce trade). The effects vary slightly, which is not surprising in view of the different underlying assumptions of the estimated models. Further, FTAs with Turkey as well as Armenia and Georgia are good for trade, 
whereas the results for Ukraine are mixed. The largest trade effect is found for Georgia, suggesting that trade with other EaPs is 11 times larger (six times for Armenia and three times for Ukraine) after the agreements entered into force. The gravity dummies (common language, common border, colonial links, same country) by and large exert significant influence on trade.

As a first robustness check we estimated the model using the two-step approach of Helpman et al. (2008). The results, available upon request, suggest the same general pattern as the alternative approaches. We find no positive effect for FTAs with Russia ${ }^{16}$ and positive and significant effects for FTAs with the EU.

As a second robustness check, given the striking variability of the EUshallow dummy across specifications, we tried to disentangle the more heterogeneous effects included in EUshallow agreements. To this end, we differentiated between the EU agreements that are classified as EIAs (Economic Integration Agreements) in Appendix Table A.1 and those that are only FTAs, with non-EaP countries outside Europe. Among the former are the agreements with Mexico in 2000, Korea in 2011, Chile in 2003 and CARIFORUM in 2008. Trade with those countries is not significantly larger after the agreements. The results appear to be driven by other agreements. We conclude that due to the high correlation between the dummies representing shallow bilateral agreements it is hard to identify separate effects using aggregate trade data. A more fruitful approach would be to use sectoral trade in combination with tariff data, a task left for further research.

Last, we place our results in the existing literature by comparing them with those reported by Kohl (2014). Also using the gravity model of trade and panel data techniques, ${ }^{17}$ Kohl estimates the effect of 166 single EIAs with data from 1950 to 2010 for 150 countries. His sample of countries differs from ours and covers a longer period (his ends in 2010, ours in 2012). Nevertheless, we make some tentative comparisons of the results obtained for agreements in which Russia is (or has been) a member with our findings. As shown by Kohl (2014, Table 5), none of the estimates for Russia's agreements with Armenia, the Kyrgyz Republic and Ukraine is statistically significant. The same applies to the ECU and the Commonwealth of Independent States (CIS) estimates; the latter is even negative $\left(-1.55^{*}\right)$ and significant at the 10 per cent level. In contrast, Kohl finds a number of positive effects on trade for EU single agreements with some Baltic states (Latvia: $0.74^{*}$ ) and among pairs of former Soviet Republics (e.g. GeorgiaKazakhstan: $0.88^{* *}$; Georgia-Turkmenistan: $0.01 *$ ).

In sum, the evidence shows that FTAs with Russia produce negligible positive or even negative effects - because, we surmise again, they stay on paper without being implemented. A tentative explanation of why trade potential with Russia remains unexploited is the poor quality of the institutional setting in the trade agreements proposed by Russia as well as the high levels of corruption perceived in some EaP countries.

\footnotetext{
16 The estimated coefficient for RUSshallow is -0.15 (-3.16) and for RUSdeep 0.05 (1.02); robust t-values are within brackets.

${ }^{17}$ Kohl (2014) estimates a fixed-effects version of the gravity model with importer-year and exporter-year effects that is similar to our results in column 2 of Table 2 and also a similar model in first differences. However, he does not tackle the zero-trade flows issue.
} 


\section{Quality of Institutions and Trade}

Our next task is to use the estimates from the preceding section to assess whether the quality of institutions has affected trade in EaP states. Georgia and Moldova surpass other $\mathrm{EaP}$ states in terms of democracy and have relatively low levels of corruption. Armenia and Ukraine are borderline cases as concerns the transition to both democracy and market economy. Mansfield et al. $(2002,2007)$ suggest that a democratic society is more prone to liberalize foreign trade than an autocratic one, since trade barriers create rents which benefit a small minority and encourage the emergence of oligarchs that veto tariff reductions.

To evaluate the direct effect of democracy and corruption on EaP exports we extend to panel data the two-step approach suggested for cross-sectional data by Eaton and Kortum (2001). ${ }^{18}$ In the first step, we estimate the gravity model with country-and-year fixed effects and bilateral fixed effects and save the coefficients obtained for the exporterand-year dummy variables $\left(\sum d_{i t} I_{i t}\right)$. The specification is similar to equation (4) but with exporter dummies varying yearly instead of every five years. ${ }^{19}$

In the second step, we use the estimated exporter-and-time fixed effects as a dependent variable and regress it on the Polity 2 variable representing democracy (see Section I) and on corruption as reported in the International Country Risk Guide (Section I, footnote 9). In this way, we aim to isolate the variation of trade that is not explained by bilateral time-invariant unobserved heterogeneity and by trade integration. Since we would like to interpret our second-step estimates as causal effects, we estimate the model with methods intended to control for endogeneity.

The first column in Table 4 shows estimates obtained from a panel data model with country fixed effects and where the regressors are the first lag (at time t-1) and the first lead (at time t+1) of the Polity2 variable. We add the lead to test for endogeneity as suggested by Baier and Bergstrand (2007). The second and third columns add time effects and allow for first-order autocorrelation AR(1) in the residuals. ${ }^{20}$ The results suggest that a one-point increase in the Polity 2 score will increase exports by about twelve percent (column 3). For example, in Azerbaijan and Belarus, with democracy scores of minus seven from the late 1990s onward, the potential for increasing trade is huge if they move toward more democratic institutions. Most of the EaP states could benefit from additional exports by improving their democracy scores. Mansfield et al. (2002) show that an effective democracy provides an incentive for politicians to enter FTAs with other countries. Such agreements provide a 'surveillance mechanism' that assures voters that politicians prevent special interests from enjoying rents provided by protection. ${ }^{21}$

We then used our proxy for corruption as a regressor. The results in column (4) of Table 4 suggest a weak negative correlation between corruption and exports. At first,

\footnotetext{
${ }^{18}$ This approach is also recommended by Head and Mayer (2015) for cross-sectional estimation.

${ }^{19}$ Alternatively, we can take the time-variant part of the residual from the gravity model estimated in Table 2, column 1, and aggregate the exponents of the residuals across exporters for use in a second- step equation as described in the text. The results, available upon request, remain virtually unchanged.

${ }^{20}$ As a robustness check we estimated the model using dynamic OLS and dynamic AR(1) models to control for endogeneity and autocorrelation by adding to the list of independent variables in levels their leads and lags in first differences. The results, which reflect long-run effects and are available upon request, remain similar. Positive and significant long-run effects are obtained for Polity2 and positive but not significant effects for corruption.

${ }^{21}$ Mansfield et al. (2002) conclude that over the postwar period pairs of democracies are twice as likely to enter a preferential trade agreement as are a democracy and an autocracy, and that the latter pair is twice as likely to enter a preferential trade agreement as a pair of autocratic countries. Furthermore, the likelihood of a given country entering into a PTA increases with both the size and the proximity of its partner country.
} 
Table 4: From Institutional Quality to Trade

\begin{tabular}{|c|c|c|c|c|c|c|}
\hline VARIABLES & $\begin{array}{c}(1) \\
\text { Panel_} \\
\text { CFE }\end{array}$ & $\begin{array}{c}(2) \\
\text { Panel_} \\
\text { CFE }\end{array}$ & $\begin{array}{c}(3) \\
\text { Panel_} \\
\text { CFE_AR(1) }\end{array}$ & $\begin{array}{c}(4) \\
\text { Panel_} \\
\text { CFE }\end{array}$ & $\begin{array}{c}(5) \\
\text { Panel_- } \\
\text { CFE }\end{array}$ & $\begin{array}{c}(6) \\
\text { Panel_- } \\
\text { CFE_AR(1) }\end{array}$ \\
\hline Polity2 (t-1, i) & $\begin{array}{r}0.124 * \\
{[0.066]}\end{array}$ & $\begin{array}{c}0.110 * * \\
{[0.052]}\end{array}$ & $\begin{array}{c}0.123 * \\
{[0.065]}\end{array}$ & & & \\
\hline Polity2 (t+1, i) & $\begin{array}{c}0.059 \\
{[0.081]}\end{array}$ & & & & & \\
\hline Corrupt $(\mathrm{t}-1, \mathrm{i})$ & & & & $\begin{array}{r}-0.158^{*} \\
{[0.082]}\end{array}$ & $\begin{array}{c}0.057 \\
{[0.064]}\end{array}$ & $\begin{array}{c}0.080 \\
{[0.079]}\end{array}$ \\
\hline Corrupt $(\mathrm{t}+1, \mathrm{i})$ & & & & $\begin{array}{r}-0.172 * \\
{[0.099]}\end{array}$ & & \\
\hline Constant & $\begin{array}{c}-0.150 \\
{[0.237]}\end{array}$ & $\begin{array}{c}-0.779 * * * \\
{[0.203]}\end{array}$ & $\begin{array}{c}0.196^{*} \\
{[0.106]}\end{array}$ & $\begin{array}{l}1.718 * * * \\
{[0.318]}\end{array}$ & $\begin{array}{r}-0.608^{*} \\
{[0.317]}\end{array}$ & $\begin{array}{l}0.409 * * * \\
{[0.149]}\end{array}$ \\
\hline Time Fixed Effects & No & Yes & No & No & Yes & No \\
\hline Observations & 397 & 424 & 372 & 246 & 266 & 246 \\
\hline R-squared & 0.031 & 0.634 & & 0.110 & 0.748 & \\
\hline Number of countries & 25 & 25 & 25 & 20 & 20 & 20 \\
\hline
\end{tabular}

Note: $* * * \mathrm{p}<0.01, * * \mathrm{p}<0.05, * \mathrm{p}<0.1$. Robust standard errors are shown within brackets. CFE denotes country fixed effects.

the causality between corruption and exports seems to be bidirectional since the lead $(\mathrm{t}+1)$ is also negative and significant, but only at the 10 per cent level. However, the coefficient turns out to be positive and not statistically significant once time dummies (or an AR(1) term) are added to the model (also, the lead term became insignificant). Indeed, a positive effect of corruption on exports could be expected in the short run if trade barriers are evaded through bribes (see Dutt and Traca, 2010; De Jong and Bogmans, 2011). For the same reason, trade could encourage corruption (reverse causality is suggested by the coefficient of the lead value). However, equally valid is the expectation of a negative long-run effect of trade on corruption, and vice versa. Our results cannot disentangle these effects, possibly due to the short time span for which data are available. Moreover, in our sample of exporters, ${ }^{22}$ most of which have trade agreements with the EU, we could expect to see the effects of corruption vary across sectors as protection is higher for agricultural products than for manufactured products. However, estimating the effect of corruption on sectoral trade is beyond the scope of this paper.

In sum, our econometric results suggest that trade agreements with the EU stimulate the EaP countries' trade significantly more than trade agreements promoted by Russia. Furthermore, DCFTAs between Georgia and the other EaPs, ${ }^{23}$ and similarly for Moldova, will also procure more trade gains than shallow FTAs. We conclude that a more

\footnotetext{
${ }^{22}$ Data on Polity2 are available for only 25 of the countries in our sample, and on corruption for 20 countries; see online Appendix Tables A.3 and A.4.

${ }^{23}$ The EaP countries have many common standards - a legacy of their common Soviet past. This is not what we mean by 'DCFTA scenario' among the EaP countries. Instead, we mean an agreement as defined by the EU containing approximation of legislation concerning sanitary and phytosanitary standards, technical regulations, international property rights, rules of origin and customs regulations and procedures as well as liberalisation of certain services. We assume a deep and comprehensive free trade agreement between EaP countries to be equivalent to the DCFTA agreements they have adopted with the EU.
} 
democratic government will boost trade by reducing trade barriers and thereby also corruption and rent-seeking.

\section{Creating a Common Neighbourhood and Saving the EaP}

Our results suggest that the optimal policy for EaP countries is to negotiate DCFTAs with both major trade partners, but especially with the EU. Russia urges the EaP countries to join the ECU, but this precludes them from having deep FTAs with the EU. ${ }^{24}$ In order to maintain control of its 'near abroad', Russia has initiated violent conflicts with Ukraine as well as with Georgia.

To resolve these conflicts it is necessary to consider the EaP countries as a common neighbourhood rather than as an exclusive 'near abroad' of one or the other bloc. Each $\mathrm{EaP}$ nation has the sovereign right to conduct its own trade policy.

The Eastern Partnership is a key option for the EaP countries. Therefore, the EU must ensure full implementation of the DCFTAs that it has signed with Georgia, Moldova and Ukraine. It must, furthermore, realize the objective shared with Russia of a 'common economic space from Lisbon to Vladivostok ${ }^{25}$ by extending an offer to negotiate a DCFTA with Russia, conditional upon Russia's cessation of hostilities with Ukraine and international supervision of elections in the disputed areas.

Such a proposal may appear unrealistic in the current situation. Russia is far from possessing the necessary economic and political characteristics required for a DCFTA. It is not a democracy; it produces few goods and services that other nations want to buy except unrefined oil, arms, chemicals and ferrous metals; it lacks a free press; and its market economy functions poorly (Gylfason et al., 2014). Moreover, Russia's international status after the annexation of Crimea and its military support of separatist forces in Donetsk and Luhansk approaches that of international pariah. However, in times of conflict it is essential to prepare for a post-conflict era. The EU must attempt to convince President Putin that Russia stands to gain more from viewing its 'near abroad' as a common neighbourhood rather than as a lost territory to be regained through military means.

Hindsight provides benefits to which foresight is not privy. After the event, it seems clear that misjudgements by both sides created a serious international conflict. We conclude by identifying some reasons for why the EaP went wrong and indicating what can be done to salvage it.

The EU overestimated the EaP states' economic and political readiness for DCFTAs. Campos (2013) stresses the 'institutional vacuum' that has characterized the EaP states since their independence. This article has shown the importance of democracy and free press as instruments both for institutional change and for providing a solid political base for international agreements. The problems that Ukraine encountered prior to initialling and signing its DCFTA reflect its weak initial conditions as concerns democracy, free press and market economy. Events have shown that the Commission's focus on institutionbuilding to qualify for a DCFTA, criticized by EaP states at the time, was correct.

Russia, too, seriously misjudged the situation. Like others, it failed to foresee that the EU would conclude DCFTAs so rapidly with Armenia, Georgia and Moldova.

\footnotetext{
${ }^{24}$ True, they could have DCFTAs with the EU but only if the Eurasian Customs Union negotiates one with the EU. This, however, would make DCFTAs with the EU for the EaP countries hostage to developments in Russia and significantly delay and dilute them compared with the DCFTAs they have already negotiated with the EU.

${ }^{25}$ Statement by President of the European Commission Barosso following the EU-Russia Summit, 28 January, 2014.
} 
Consequently, it hastily imposed ill-conceived counter-measures. Russia also underestimated the strong popular support that existed in parts of Ukraine for the democratic values that the EU represents. Misjudgements by both sides thus created a serious conflict centred on Ukraine with ramifications for Georgia and Moldova.

\section{Conclusion}

This article suggests that the $\mathrm{EaP}$ states stand to gain significantly from trade agreements with the EU, whether deep or shallow, while the customs union proposed by Russia is likely to provide negligible benefits. It also shows that the EaP states stand to gain significantly from FTAs with each other. While further research is necessary to ascertain more precisely the size of these benefits, their rough relative magnitude is supported by other studies (e.g. Kohl, 2014). These benefits suggest that the EU should ensure that the EaP survives its current difficulties. True, the EU's soft power is ineffective as a response to Russia's hard power. But the EU cannot leave Ukraine to deal with Russia on its own as best it can. This would soon put Georgia and Moldova in the same situation Ukraine is in now. It would also have serious consequences for the credibility of the EU. An option available to the EU is to internationalize the conflict, involving the United Nations and the OSCE (Organization for Security and Co-operation in Europe) to a significantly larger extent than at present. It will need to complement its own soft power with the hard power of the international organizations to separate the warring factions, maintain law and order and arrange referenda so that the populations in disputed regions can express their views concerning national borders in a democratic manner. The EU can also negotiate a DCFTA with Russia, thereby creating a 'single economic space from Lisbon to Vladivostok' as that country has requested. This economic space would include as a 'common neighbourhood' those EaP states willing and able to participate.

\section{Correspondence:}

Inmaculada Martínez-Zarzoso

Georg-August University Göttingen

and University Jaume I, Castellón

email: imartin@uni-goettingen.de

\section{References}

Anderson, J.E. and van Wincoop, E. (2003) 'Gravity with Gravitas: A Solution to the Border Puzzle'. American Economic Review, Vol. 93, No. 1, pp. 170-92.

Baier, S. and Bergstrand, J.H. (2007) Do free trade agreements actually increase members International trade?. Journal of International Economics, Vol. 71, No. 1, pp. 72-95.

Baltagi, B., Egger, P. and Pfaffermayr, M. (2014) 'Panel Data Gravity Models of International Trade'. CESifo Working Paper No. 4616.

Campos, N. (2013) 'What Drives Protests in the Ukraine? This Time it is Institutions,' VoxEU.org, 22 December. Available at «http://www.voxeu.org/article/what-drives-protests-ukraine»

Davies, R. and Kristjánsdóttir, H. (2010) 'Fixed Costs, Foreign Direct Investment, and Gravity with Zeros'. Review of International Economics, Vol. 18, No. 1, pp. 47-62.

De Jong, E. and Bogmans, C. (2011) 'Does Corruption Discourage International Trade?' European Journal of Political Economy, Vol. 27, pp. 385-98. 
De Sousa, J. (2012) 'The Currency Union Effect on Trade is Decreasing over Time'. Economics Letters, Vol. 117, No. 3, pp. 917-20.

Djankov, S. and Freund, C. (2002) 'Trade Flows in the Former Soviet Union: 1989-1996,' Journal of Comparative Economics, Vol. 30, No. 1, pp. 76-90.

Dutt, P. and Traca, D. (2010) 'Corruption and Bilateral Trade Flows: Extortion or Evasion?' Review of Economics and Statistics, Vol. 92, No. 4, pp. 843-60.

Eaton, J. and Kortum, S. (2001) 'Trade in Capital Goods'. European Economic Review, Vol. 45, No. 7, pp. 1195-235.

Eaton, J., Kortum, S. and Sotelo, S. (2012) 'International Trade: Linking Micro and Macro'. NBER Working Paper 17864, National Bureau of Economic Research.

Eicher, T.S., Henn, C. and Papageorgiou, C. (2012) 'Trade Creation and Trade Diversion Revisited: Accounting for Model Uncertainty and Natural Trading Partner Effects'. Journal of Applied Econometrics, Vol. 27, pp. 296-321.

Feenstra, R. (2004) Advanced International Trade (Princeton, NJ: Princeton University Press).

Fidrmuc, J. and Fidrmuc, J. (2003) 'Disintegration and Trade'. Review of International Economics, Vol. 11, No. 5, pp. 811-29.

Gylfason, T., Martínez Zarzoso, I. and Wijkman, P.M. (2014) 'Can and Should the EU's Eastern Partnership be Saved?' CESIFO Working Paper No. 4869, July.

Head, K. and Mayer, T. (2015) 'Gravity Equations: Workhorse, Toolkit, and Cookbook'. In Gopinath, G., Helpman, E. and Rogoff, K. (eds.), Handbook of International Economics, Vol. 4 (Amsterdam: Elsevier-North Holland).

Heckman, J.J. (1979) 'Sample Selection Bias as a Specification Error'. Econometrica, Vol. 47, 153-61.

Helpman, E., Melitz, M. and Rubinstein, Y. (2008) 'Estimating Trade Flows: Trading Partners and Trading Volumes'. Quarterly Journal of Economics, Vol. 123, No. 2, pp. 441-87.

Kohl, T. (2014) 'Do We Really Know that Trade Agreements Increase Trade?' Review of World Economics, Vol. 150, No. 3, pp. 443-69.

Kubicek, P. (2009) 'Problems of post-post-communism: Ukraine after the Orange Revolution', Democratization, Vol. 16, No. 2, pp. 323-43.

Libman, A. (2007) 'Regionalisation and Regionalism in the Post-Soviet Space: Current Status and Implications for Institutional Development'. Europe-Asia Studies, Vol. 59, No. 3, pp. 401-30.

Manning, W. and Mullahy, J. (2001) 'Estimating Log Models: To Transform or Not to Transform?'. Journal of Health Economics, Vol. 20, No. 4, pp. 461-94.

Mansfield, E.D., Milner, H.V. and Pevehouse, J.C. (2007) 'Vetoing Cooperation: The Impact of Veto Players on Preferential Trading Arrangements'. British Journal of Political Science, Vol. 37, No. 3, pp. 403-32.

Mansfield, E.D., Milner, H.V. and Rosendorff, B.P. (2002) 'Why Democracies Cooperate More: Electoral Control and International Trade Agreements'. International Organization, Vol. 56, No. 3, pp. 477-513.

Martínez-Zarzoso, I. (2013) 'The Log of Gravity Revisited'. Applied Economics, Vol. 45, No. 3, pp. 311-27.

Olcott, M.B., Aslund, A. and Garnett, S. (1999) Getting it Wrong: Regional Cooperation and the Commonwealth of Independent States, (Washington, D.C.: Carnegie Endowment for International Peace).

Wirminghaus N. (2012) 'Ephemeral Regionalism: The Proliferation of (Failed) Regional Integration Initiatives in Post-Soviet Eurasia'. In Boerzel, T., Goltermann, L., Lohaus, M. and Striebinger, K. (eds), Roads to Regionalism: Genesis, Design, and Effects of Regional Organisations (Aldershot: Ashgate).

World Development Indicators. (2014) The World Bank, (Washington, D.C.). 


\section{Supporting Information}

Additional Supporting Information may be found in the online version of this article at the publisher's web-site:

Table A1: List of agreements

Table A2: List of countries

Table A3: Polity2 scores for exporters

Table A4: Transparency scores for exporters

On-Line Appendix: Post-Soviet economic integration agreements 